\title{
Oxygen-limited metabolism in the methanotroph Methylomicrobium buryatense 5GB1C
}

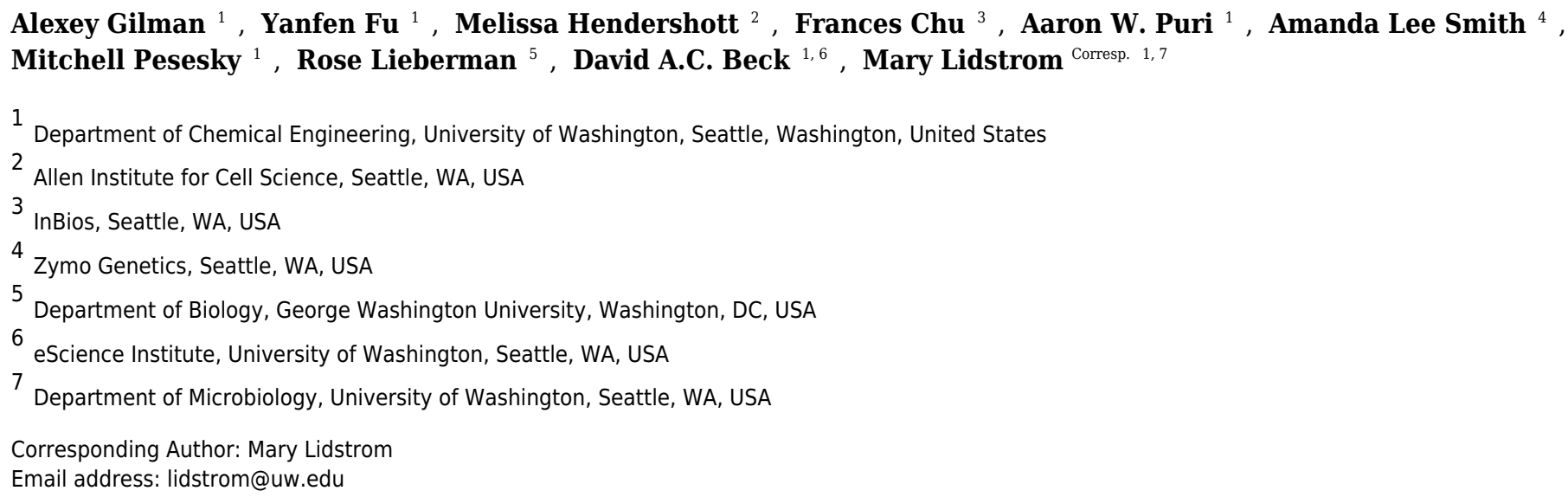

The bacteria that grow on methane aerobically (methanotrophs) support populations of non-methanotrophs in the natural environment by excreting methane-derived carbon. One group of excreted compounds are short-chain organic acids, generated in highest abundance when cultures are grown under $\mathrm{O}_{2}$-starvation. We examined this $\mathrm{O}_{2}$-starvation condition in the methanotroph Methylomicrobium buryatense 5GB1. The M. buryatense $5 G B 1$ genome contains homologs for all enzymes necessary for a fermentative metabolism, and we hypothesize that a metabolic switch to fermentation can be induced by low- $\mathrm{O}_{2}$ conditions. Under prolonged $\mathrm{O}_{2}$-starvation in a closed vial, this methanotroph increases the amount of acetate excreted about 10-fold, but the formate, lactate, and succinate excreted do not respond to this culture condition. In bioreactor cultures, the amount of each excreted product is similar across a range of growth rates and limiting substrates, including $\mathrm{O}_{2}$-limitation. A set of mutants were generated in genes predicted to be involved in generating or regulating excretion of these compounds and tested for growth defects, and changes in excretion products. The phenotypes and associated metabolic flux modeling suggested that in $M$. buryatense 5GB1, formate and acetate are excreted in response to redox imbalance. Our results indicate that even under $\mathrm{O}_{2}$ starvation conditions, $M$. buryatense 5GB1 maintains a metabolic state representing a combination of fermentation and respiration metabolism. 
1 Oxygen-limited metabolism in the methanotroph Methylomicrobium buryatense 5GB1C

3 Alexey Gilman ${ }^{1}$, Yanfen $\mathrm{Fu}^{1}$, Melissa Hendershott ${ }^{2}$, Frances $\mathrm{Chu}^{3}$, Aaron W. Puri ${ }^{1}$, Amanda Lee

4 Smith $^{4}$, Mitchell Pesesky ${ }^{1}$, Rose Lieberman ${ }^{5}$, David A.C. Beck ${ }^{1,6}$, and Mary E. Lidstrom ${ }^{\text {Corresp. 1,7 }}$

$6{ }^{1}$ Departments of Chemical Engineering, University of Washington, Seattle, WA, USA

$7 \quad{ }^{2}$ Allen Institute for Cell Science, Seattle, WA, USA

$8{ }^{3}$ InBios, Seattle, WA, USA

$9 \quad{ }^{4}$ Zymo Genetics, Seattle, WA, USA

$10{ }^{5}$ Department of Biology, George Washington University, WA, USA

$11{ }^{6}$ eScience Institute, University of Washington, Seattle, WA, USA

$12{ }^{7}$ Departments of Microbiology, University of Washington, Seattle, WA, USA

13

16 Running title: Methanotrophic oxygen-limited metabolism

20 \#Corresponding author:

21 Mary Lidstrom

22 Benjamin Hall IRB Rm 440, 616 NE Northlake Place, Seattle, WA 98105 USA

23 Tel: (206) 616-5282; lidstrom@uw.edu 


\section{ABSTRACT}

25 The bacteria that grow on methane aerobically (methanotrophs) support populations of non-

26 methanotrophs in the natural environment by excreting methane-derived carbon. One group of

27 excreted compounds are short-chain organic acids, generated in highest abundance when cultures

28 are grown under $\mathrm{O}_{2}$-starvation. We examined this $\mathrm{O}_{2}$-starvation condition in the methanotroph

29 Methylomicrobium buryatense 5GB1 The M. buryatense 5GB1 genome contains homologs for

30 all enzymes necessary for a fermentative metabolism, and we hypothesize that a metabolic

31 switch to fermentation can be induced by low-oxygen conditions. Under prolonged $\mathrm{O}_{2^{-}}$

32 starvation in a closed vial, this methanotroph increases the amount of acetate excreted about 10-

33 fold, but the formate, lactate, and succinate excreted do not respond to this culture condition. In

34 bioreactor cultures, the amount of each excreted product is similar across a range of growth rates

35 and limiting substrates, including $\mathrm{O}_{2}$-limitation. A set of mutants were generated in genes

36 predicted to be involved in generating or regulating excretion of these compounds and tested for

37 growth defects, and changes in excretion products. The phenotypes and associated metabolic flux

38 modeling suggested that in $M$. buryatense 5GB1, formate and acetate are excreted in response to

39 redox imbalance. Our results indicate that even under $\mathrm{O}_{2}$-starvation conditions, M. buryatense

40 5GB1 maintains a metabolic state representing a combination of fermentation and respiration

41 metabolism.

\section{IMPORTANCE}

44 The ability of methanotrophs to excrete short-chain acids has implications for environmental consumption of the potent greenhouse gas methane. Under the $\mathrm{O}_{2}$-starvation conditions similar

46 to those in many natural environments where methanotrophs are found, formate and acetate are 
47 major products, with lactate and succinate also generated. This methane-derived carbon is involved in supporting a community of non-methanotrophs in such natural environments. This work also suggests approaches for maximizing excretion of specific products for bioconversion applications of methanotrophs.

\section{INTRODUCTION}

53 Methanotrophs are a group of bacteria able to grow on methane as sole carbon and energy source

54 (Whittenbury et al., 1970). They play an important role in natural habitats, retaining methane

55 carbon in ecosystems and mitigating emissions of this potent greenhouse gas (Knief 2015;

Chistoserdova 2015). The subgroup of methanotrophs requiring $\mathrm{O}_{2}$ for activation of methane (the aerobic methanotrophs) are important in mitigating methane emissions from soil and aquatic environments (Ruff et al., 2015). Aerobic methanotrophs often live at the low end of the $\mathrm{O}_{2}$ gradient in their natural environments (Knief, 2015), creating selective pressure to develop mechanisms for coping with $\mathrm{O}_{2}$-starvation. In addition, such bacteria are also of interest for

61 developing commercial gas-to-liquid processes, converting methane to fuels and chemicals 62 (Kalyuzhnaya et al., 2015a).

Recently, it has been shown that a gamma-proteobacterial methanotroph, Methylomicrobium

64 alcaliphilum 20Z, contains a highly efficient version of the ribulose monophosphate cycle for

65 formaldehyde assimilation, that could theoretically allow for a fermentation type of metabolism,

66 with $\mathrm{O}_{2}$ used for activating the methane molecule, but not as a terminal electron acceptor

67 (Kalyuzhnaya et al., 2013). Evidence was provided that genes encoding enzymes of such a

68 pathway are widespread in gamma-proteobacterial methanotrophs, and are transcriptionally up-

69 regulated when cells are cultured under $\mathrm{O}_{2}$-starvation conditions, concomitant with excretion of 
70 putative fermentation end products (Kalyuzhnaya et al., 2013). These results are intriguing, both

71 for the potential of methanotrophs to cross-feed non-methanotrophs with methane-derived

72 carbon in natural communities (Radajewski et al., 2003; Oshkin et al., 2015), and for the

73 potential to manipulate methanotrophic metabolism to generate excreted products (Kalyuzhnaya

74 et al., 2015a).

75 The genome of $M$. buryatense 5GB1 predicts a set of genes that could be involved in 76 fermentation of formaldehyde, via the ribulose monophosphate cycle and the EMP pathway

77 and/or XFP pathway (Fig. 1; de la Torre et al., 2016; Henard et al., 2017), similar to such genes

78 identified in M. alcaliphilum 20Z (Kalyuzhnaya et al., 2013). These genes predict a set of end

79 products that could be generated, including formate, acetate, lactate, succinate, and $\mathrm{H}_{2}$.

80 We have examined this mode of $\mathrm{O}_{2}$-starved metabolism in a different gamma-proteobacterial

81 methanotroph, Methylomicrobium buryatense 5GB1, for which formate, acetate, and lactate

82 excretion have been reported (Gilman et al., 2015; Henard et al., 2016, 2017). This

83 methanotroph has become an attractive model system for carrying out basic research studies of

84 methanotrophs, with a genome sequence (Khmelenina, 2013), a set of genetic tools (Puri et al.

85 2015, Yan et al. 2016, Henard et al., 2016), a genome-scale metabolic model (de la Torre et al.,

86 2016), a metabolic flux database (Fu et al., 2017) and a set of transcriptomic, metabolomic, and

87 bioreactor datasets available (de la Torre et al., 2016; Gilman et al., 2015; Fu et al., 2017; Henard

88 et al., 2017). We hypothesized that, like M. alcaliphilum 20Z, M. buryatense 5GB1 would switch

89 to a primarily fermentative metabolic state under $\mathrm{O}_{2}$-starvation, increasing its excretion of

90 organic end products. We have used a variety of approaches to determine how the excretion

91 products are generated under $\mathrm{O}_{2}$-starvation, and have used metabolic modeling coupled to 
92 measured parameters to predict the structure of the metabolic network occurring during this

93 mode of growth.

95 MATERIALS AND METHODS

96 Strains and culture conditions

97 M. buryatense 5GB1C is a derivative of M. buryatense 5GB1 created by deliberate curing of its

$9880 \mathrm{kbp}$ plasmid. M. buryatense 5GB1C was not found to have a growth defect or significant

99 changes in chromosomal gene expression in the absence of its plasmid, but this did allow for

100 genetic manipulation (Puri et al. 2015). For this study we used M. buryatense 5GB1 for most

101 wild-type experiments, while all gene knockouts were completed in the 5GB1C background.

102 Two biological replicates of wild-type $M$. buryatense 5GB1C were grown in the bioreactor under

103 slow growth $\mathrm{O}_{2}$-starvation conditions for comparison to the aa3 cytochrome oxidase mutant

104 strain. M. buryatense 5GB1 and its derivatives were grown in a modified NMS medium with

105 methane at $30^{\circ} \mathrm{C}$, as previously described (Puri, Owen et al. 2015). Methylobacter

106 tundripaludum 31/32 and Methylomonas sp. LW13 (Kalyuzhnaya et al., 2015b) were grown in

107 NMS medium at $18^{\circ} \mathrm{C}$ and $30^{\circ} \mathrm{C}$, respectively, as previously described for Methylobacter

108 tundripaludum 21/22 (Puri et al., 2017). The M. buryatense 5G genome sequence is deposited in

109 GenBank/EMBL under the accession numbers AOTL01000000, KB455575, and KB455576

110 (Khmelenina, Beck et al. 2013). M. buryatense 5GB1 cultures grown in vials for $\mathrm{O}_{2}$-starvation

111 experiments were inoculated at $0.05 \mathrm{OD}_{600}$ from an overnight culture and the vial was given a

112 normal headspace of $25 \% \mathrm{CH}_{4}, 75 \%$ air. Cultures were incubated with shaking at $30^{\circ} \mathrm{C}$ for 5

113 days. For growth curve experiments, cultures were set up the same way, and samples were taken 
114 at various time points to measure $\mathrm{OD}_{600}$ and excretion products. For M. tundripaludum 31/32,

115 incubation temperature was $18^{\circ} \mathrm{C}$.

116

117 Product measurements

118 Measurements of excreted organic acids were carried out either by NMR, as previously

119 described (Kalyuzhnaya et al., 2013), or by ion chromatography, as follows. $1 \mathrm{ml}$ of cell culture

120 was taken from vial, and centrifuged at $13000 \mathrm{rpm}$ for 5 minutes. The supernatant was carefully

121 transferred into a new syringe and filtered through a $0.2 \mu \mathrm{m}$ syringe filter (Milipore syringe filter,

122 Fisher). 600-650 $\mu 1$ filtered supernatant was transferred into PolyVials (ThermoScientific) for

123 injection. Analysis was carried out on an ICS-1600 Ion chromatography system equipped with a

124 ICE-AS6 $9 \times 250 \mathrm{~mm}$ column. $225 \mu \mathrm{l}$ was injected into the system, eluted with $1 \mathrm{ml} / \mathrm{min}$ of

$1250.5 \mathrm{mM}$ heptafluorobutyric acid (HFBA, ThermoScientific). The column was regenerated with

$1265 \mathrm{mM}$ tetrabutylammonium hydroxide (TBAOH, ThermoScientific) aqueous solution. All

127 cultures were assessed in two separate biological replicates and results are reported as an average.

128

129 Bioreactor

130 Bioreactor experiments were carried out in a New Brunswick BioFlo 310 bioreactor (Eppendorf,

131 Inc. Enfield, CT, USA), and off gas samples were measured using Shimadzu gas chromatograph

132 GC2014 (Shimadzu Scientific Instruments, Inc. Columbia, MD, USA) as described previously

133 (Gilman et al., 2015), using premixed gas tanks $\left(20 \% \mathrm{CH}_{4}, 5 \% \mathrm{O}_{2}, 75 \% \mathrm{~N}_{2}\right)$ and a dilution rate

134 (equal to the growth rate at steady state) of $0.03 \mathrm{hr}^{-1}$.

135 Steady state ${ }^{13} \mathrm{C}$ tracer experiments 
136 Steady state ${ }^{13} \mathrm{C}$ tracer experiments were performed on the aa3 cytochrome oxidase mutant strain

137 in methane, as described previously (Fu et al., 2017). $5 \mathrm{ml}$ of preculture was inoculated from

138 plate, cultured in $25 \%{ }^{13} \mathrm{C}$ methane (Sigma) to full growth, and transferred into $50 \mathrm{ml}$ fresh

139 NMS2 medium with OD600 $=0.01$ with $25 \%{ }^{13} \mathrm{C}$ methane (sigma) until mid-log phase. The cell

140 culture was quenched, extracted and measured using LC-MS/MS with previously described

141 method (Fu et al., 2017).

\section{RNAseq}

144 RNA was extracted as previously described (Chu and Lidstrom, 2016). RNA sequencing was

145 performed by GENEWIZ (South Plainfield, NJ, USA) using Illumina HiSeq2500 1x50 (single

146 ended) reads. The raw reads from the sequencing facility were aligned to the annotated $M$.

147 buryatense 5G genome as downloaded from JGI's IMG on July 14, 2017 (Markowitz et al, 2014).

148 Alignment was performed using BWA version 0.7.12-r1044 using the BWA-MEM algorithm

149 and default parameters (Li and Durbin, 2010). The alignments were post-processed into sorted

150 BAM files with SAMTools version 1.2-232-g87cdc4a (Li et al., 2009). Reads were attributed to

151 open reading frames (ORFs) using the htseq-count tool from the 'HTSeq' framework version

1520.8 .0 in the 'intersection-nonempty' mode (Anders et al., 2015). Differential abundance analysis

153 was performed with DESeq2 1.2.10 (Anders and Huber, 2010; Anders et al., 2013) using R 3.3.1.

154 Genes were considered to be differentially expressed if there was an average change of greater

155 than 2-fold when comparing normalized counts as well as an adjusted p-value of less than 1E-05

156 (Anders and Huber, 2010).

157

158 Mutants and Genetic Manipulations 
159 Gene knockout constructs were generated using assembled PCR products that were

160 electroporated into M. buryatense 5GB1C, as previously described (Chu and Lidstrom 2016, Yan,

161 Chu et al. 2016). Double mutants were constructed with the same approach into unmarked single

162 mutant M. buryatense 5GB1C strain. Plasmids were constructed by Gibson assembly (Gibson,

163 Young et al. 2009).

164

165 Flux balance analysis with Cobrapy

166 The genome scale model published earlier (de la Torre et al., 2016) was used in this study with a

167 few modifications. The constraint of flux partition between the EMP and ED pathways was

168 removed by replacing reaction PYK and EDA with reactions that produced regular pyruvate. The

169 secretion reactions of organic acids (specifically, formate, acetate, succinate and lactate) were

170 decoupled from the biomass equation 'BIOMASS_M5GB1'. The respiration summary reaction

171 was bound to 0 , and was replaced with full electron transport chain reactions. The methane

172 oxidation reaction (pMMO) was modified with ubiquinol as electron acceptor, methanol

173 oxidation reaction (MXA) and nitrate reductase were also modified accordingly. CobraPy

174 (Ebrahim et al., 2013) (version 0.4.1) was used in this study for flux balance analysis with cglpk

175 as solver. Python scripts and input model files (in .xml files) are available in zenode repository

176 https://zenodo.org/badge/latestdoi/93199234

177

178 RESULTS

179 Excretion products in vial-grown cultures under $\mathrm{O}_{2}$-starvation

180 M. buryatense 5GB1 was grown in closed vials under $\mathrm{O}_{2}$-starvation conditions, formate, acetate,

181 and succinate were detected, lactate, hydroxybutyrate, and $\mathrm{H}_{2}$ were not detectable (Fig. 2). 
182 Compared to previously reported M. buryatense 5GB1 bioreactor cultures, the acetate was over

183 10-fold higher in the vial cultures, but the formate was similar to the values in the bioreactor

184 cultures (Fig. 2; Gilman et al., 2015). Since the Methylomicrobium strains tested for these

185 excretion products so far are both haloalkaliphiles (Kaluzhnaya et al., 2001), we also assessed

186 two different gamma-proteobacterial methanotrophs isolated from a freshwater lake,

187 Methylobacter tundripaludum 31/32 and Methylomonas strain LW13 (Kalyuzhnaya et al.,

188 2015b), and showed that these strains generate formate, acetate, and succinate under these

189 growth conditions, but lactate and hydroxybutyrate were not detected (Fig. 2).

190

191 Excretion products and $\mathrm{O}_{2} / \mathrm{CH}_{4}$ uptake ratio in bioreactor cultures

192 As reported previously, formate, acetate, and lactate had been detected in bioreactor cultures of

193 M. buryatense 5GB1, with similar values in cultures grown on methane at maximum growth rate

$194\left(0.22-0.24 \mathrm{hr}^{-1}\right)$ and under methane- and $\mathrm{O}_{2}$-limitation grown at about half the maximum growth

195 rate (Gilman et al., 2015). M. buryatense 5GB1 was tested in this study for excreted products

196 under the slower growth conditions used for M. alcaliphilum 20Z, in an $\mathrm{O}_{2}$-limited bioreactor

197 operated at a growth rate of $0.035-0.036 \mathrm{hr}^{-1}$. Samples were taken at steady-state for excreted

198 products and RNAseq analysis, and the $\mathrm{O}_{2} / \mathrm{CH}_{4}$ ratio was determined. The excreted products and

$199 \mathrm{O}_{2} / \mathrm{CH}_{4}$ ratios were compared to the values previously published for $M$. buryatense 5GB1 $\mathrm{O}_{2}$ -

200 limited and methane-limited cultures at a higher growth rate $\left(0.12 \mathrm{hr}^{-1}\right)$ (Table 1; Gilman et al.,

201 2015). The bioreactor cultures did not show an increase in the excreted products compared to

202 full $\mathrm{O}_{2}$ bioreactor cultures, and the $\mathrm{O}_{2} / \mathrm{CH}_{4}$ ratios were similar to those previously published for

203 the faster growth $\mathrm{O}_{2}$-limited cultures (Gilman et al., 2015). 


\section{Transcriptomics}

206 RNA samples from the slower growth $\mathrm{O}_{2}$-limited cultures were used for RNAseq analysis and

207 compared to RNA samples from the previously published bioreactor conditions noted above $\left(\mathrm{O}_{2^{-}}\right.$

208 limited and $\mathrm{CH}_{4}$-limited, both at a growth rate of $0.12 \mathrm{hr}^{-1}$; Table 2; Table S1). Only a few of the

209 genes predicted to be involved in a fermentation type metabolism (Fig. 1) showed significant

210 changes in transcription, when compared to either the $\mathrm{O}_{2}$-limited or $\mathrm{CH}_{4}$-limited cultures (Table

211 3). The gene most strongly regulated was that for bacteriohemerythrin (MBUTDRAFT_0310),

212 encoding a protein proposed to be involved in $\mathrm{O}_{2}$-scavenging (Chen et al., 2012) and shown to be

213 induced in M. alcaliphilum 20Z under fermentation conditions (Kalyuzhnaya et al., 2013). This

214 gene was upregulated over two orders of magnitude when compared to the high $\mathrm{O}_{2}$ condition

$215\left(\mathrm{CH}_{4}\right.$-limited), 2-fold when the faster growth $\mathrm{O}_{2}$-limitation was compared to the $\mathrm{CH}_{4}$-limitation

216 condition, and 10-fold, when the slower-growth $\mathrm{O}_{2}$-limitation condition was compared to the

217 faster growth $\mathrm{O}_{2}$-limitation condition. This result suggests that the slower growth $\mathrm{O}_{2}$-limitation

218 condition was more $\mathrm{O}_{2}$-stressed than the higher growth $\mathrm{O}_{2}$-limitation condition. Other genes in

219 this list that showed a pattern of upregulation in response to low $\mathrm{O}_{2}$ were those encoding the

220 three subunits of a predicted ba3-type cytochrome oxidase and one of the subunits of the aa3

221 cytochrome oxidase. One of the few gene clusters predicted to be involved in fermentation that

222 showed consistent and statistically significant up-regulation under the slower growth condition

223 was that for the first three genes encoding hydrogenase (MBUTDRAFT1387-89), with the genes

224 showing 1.9-2.6 fold change compared to the faster growth $\mathrm{O}_{2}$-limited condition. However,

225 since $\mathrm{H}_{2}$ was not detected under these conditions, this expression change did not result in net $\mathrm{H}_{2}$

226 evolution. These genes showed a significant but small decrease in expression when the faster

227 growth $\mathrm{O}_{2}$-limited culture was compared to the faster growth methane-limited culture. Other 
228 genes showing an upregulation response to the slower growth condition compared to the faster

229 growth $\mathrm{O}_{2}$-limited condition were those for $x f p 1$, encoding one of the phosphoketolase genes

230 (METBUDRAFT_1551) at 2.1 fold, and one of the genes encoding a 6-phosphogluconate

231 dehydrogenase homolog (METBUDRAFT_3313), 1.6 fold. One of the subunits of one of the

232 NADH dehydrogenase clusters (METBUDRAFT_2827) showed downregulation under slow

233 growth, suggesting it might be growth-rate regulated.

235 The entire set of genes was assessed to determine whether any recognizable metabolic trends

236 could be extracted from the gene expression pattern (Table S1). The slower growth $\mathrm{O}_{2}$-limited

237 cultures showed significant induction of the entire set of nitrogenase genes

238 (METBUDRAFT_4082-4154) while in the other RNAseq datasets the expression levels were

239 near background, suggesting nitrogen-stress at the slower growth condition. Further work

240 showed that only when the nitrate was increased to 3-fold the normal amount was nitrogenase

241 repressed in the bioreactor cultures at the slower growth condition, but that level of nitrate

242 caused growth inhibition (data not shown). Therefore, it was not used for further studies.

243 However, no other general metabolic trends could be discerned from this dataset.

245 Mutant phenotypes

246 In order to assess the role of specific gene products in the generation of excreted organic acids, a

247 set of 25 deletion mutations were generated (Table 3). These included genes predicted to be

248 involved in generating $\mathrm{H}_{2}$, formate, acetate, lactate, and succinate, genes predicted to be involved

249 in utilization of NADH, and genes predicted to be involved in generation of NADH. The latter

250 two categories were included to assess the role of NADH balance in excretion phenotypes. In 
251 addition, attempts were made to generate a double mutant defective in acetate kinase and

252 acetylCoA synthase, to assess the role of this interconversion in acetate production, but we were

253 unable to obtain a null mutant.

254

255 Only one mutant showed a noticeable growth defect on agar plates, the mutant deleted in the aa3

256 cytochrome oxidase $(c t a C D)$. In liquid culture with sufficient $\mathrm{O}_{2}$, this mutant had a maximum

257 growth rate of $0.06 \mathrm{hr}^{-1}$ and a maximum OD600 of 0.2-0.4. Excretion products were tested for

258 vial cultures of all mutants incubated for 5 days. Only three mutants showed a significant change

259 in excretion products compared to the wild type (Fig. 2), the aa3 cytochrome oxidase mutant, the

260 mutant in the predicted molybdenum-dependent formate dehydrogenase ( $f d h 2)$ and the mutant in

261 one of the predicted NADH dehydrogenase genes (ndh2). In the last two cases, formate excretion

262 increased over two orders of magnitude, acetate decreased about 2-fold, and succinate excretion

263 decreased about an order of magnitude, while in the aa3 cytochrome oxidase mutant, formate

264 excretion increased about an order of magnitude, and acetate and succinate excretion decreased

265 3-to 5-fold (Fig. 2).

266

267 Since 3 of the functions tested had two predicted homologs in the genome, double mutants were

268 generated for 6-phosphogluconate dehydrogenase ( $g n d$ ), NADH dehydrogenase ( $n d h)$, formate

269 dehydrogenase $(f d h)$ and phosphoketolase $(x f p)$. Only the $f d h 1 / f d h 2$ double mutant showed a

270 growth defect on agar plates. In liquid culture, it grew with a growth rate of $0.04 \pm 0.01 \mathrm{hr}^{-1}$. In

271 the case of the first two double mutants, the excretion phenotypes in vial cultures were no

272 different from the single mutants. In the case of the $x f p 1 / x f p 2$ double mutant, the formate and

273 acetate levels did not change significantly, but the succinate levels dropped almost two orders of 
274 magnitude. The excretion profile of the $f d h 1 / f d h 2$ double mutant was similar to that of the $f d h 2$

275 single mutant.

276

277

aa3 cytochrome oxidase mutant strain analysis

278 Given the severe growth defect of the mutant deleted in the aa3 cytochrome oxidase, it might be

279 expected that this strain could only grow via a fermentation-like metabolism, without significant

280 aerobic respiration. Further experiments were carried out to assess this possibility. The aa3

281 cytochrome oxidase mutant strain was grown in the bioreactor under $\mathrm{O}_{2}$-limited conditions

282 similar to the wild type, with a growth rate of $0.034-0.035 \mathrm{hr}^{-1}$. At this growth rate it was

283 possible to achieve steady-state culture of this mutant strain, and at steady-state conditions the

284 levels of formate and acetate were both higher than the wild type (Fig. 2). The $\mathrm{O}_{2} / \mathrm{CH}_{4}$ ratio was

285 1.1, similar to that for the wild-type (Table 1). RNA samples from the steady-state culture were

286 used for RNAseq analysis but few differences above 2-fold with significant p-values were

287 observed comparing the mutant to the wild type, other than those involved in nitrogen

288 metabolism (Table S1). None of the genes predicted to be involved in a fermentation-type

289 metabolism showed significant changes in the aa3 cytochrome oxidase mutant compared to the

290 wild type (Table 3).

291

292 FBA modeling

293 An existing genome-scale FBA model (de la Torre et al., 2016) was updated to include the

294 fermentation reactions shown in Fig. 1 as well as expanded to include individual electron

295 transport chain reactions (Table S2, supplementary material). Secreted products were uncoupled

296 from the biomass equation, to facilitate changes to these values. Bioreactor values for methane 
297 uptake rates were used to simulate specific cases using COBRApy (Table 4). In the first case, no

298 other constraints were applied, and the model predicts flux ratios similar to those for unrestricted

299 methane growth, decreased to accommodate the lower methane uptake rates, with a predicted

300 growth rate average of $0.042 \pm 0.002 \mathrm{hr}^{-1}$. When the additional constraint of the $\mathrm{O}_{2} / \mathrm{CH}_{4}$ ratio

301 was applied to accommodate the restricted $\mathrm{O}_{2}$ availability, the model predicts a growth rate

302 average of $0.035 \pm 0.001 \mathrm{hr}^{-1}$, similar to the experimental growth rate average of $0.0355 \mathrm{hr}^{-1}$.

303 Finally, the constraints of the measured formate, acetate, and succinate values were applied, and

304 the results suggested a growth rate average of $0.0335 \pm 0.001 \mathrm{hr}^{-1}$, also similar to the

305 experimental values. The $a a 3$ oxidase mutant strain was also modeled using the bioreactor values

306 from Table 2 and the full set of constraints. The results predicted a growth rate average of 0.046

$307 \pm 0.004 \mathrm{hr}^{-1}$, significantly greater than the experimental growth rate average of $0.0345 \mathrm{hr}^{-1}$.

308

309 Since this mutant strain appeared to carry out a fermentation-type metabolism in the presence of

310 higher $\mathrm{O}_{2}$, it presented the possibility to apply steady-state metabolic flux analysis to assess

311 metabolic flux through the pathways downstream of the pyruvate node (Fu et al., 2017). Such

312 analysis is difficult to carry out under $\mathrm{O}_{2}$-limitation, due to the requirement for gas flow-through

313 to maintain steady-state low $\mathrm{O}_{2}$ levels, and the quantities of ${ }^{13} \mathrm{CH} 4$ required. At higher $\mathrm{O}_{2}$, it is

314 possible to carry out this analysis in a closed vial (Fu et al., 2017), making metabolic flux

315 analysis of the aa3 oxidase mutant strain feasible. Metabolic flux analysis was carried out in the

$316 a a 3$ oxidase mutant strain, and it was shown that in keeping with the model predictions, the TCA

317 cycle is complete as it is in the WT strain (Fu et al., 2017), contributing to $45 \%$ of de novo

318 malate synthesis (Fig. 3). 


\section{DISCUSSION}

321 The ability of aerobic methanotrophs to excrete short-chain organic acids has implications for

322 both environmental and industrial applications of methanotrophs (Knief 2015; Chistoserdova

323 2015; Kalyuzhnaya et al., 2015a). Understanding the metabolism involved in this conversion is

324 an important step in defining how methane is consumed in natural environments, as well as

325 moving towards cost-effective processes for methane biotechnology. In this work, we have

326 shown that Methylomicrobium buryatense 5GB1 shows different excretion profiles as compared

327 to a related gamma-proteobacteriual methanotroph Methylomicrobium alcaliphilum 20Z,

328 highlighting differences in the metabolic networks of these two haloalkaliphilic methanotrophs.

329 Although M. alcaliphilum $20 \mathrm{Z}$ increases multiple excretion products (formate, acetate, lactate,

330 succinate, and $\mathrm{H}_{2}$ ) in response to $\mathrm{O}_{2}$-starvation (Kalyuzhnaya et al., 2013), M. buryatense 5GB1

331 only shows an increase for acetate. In addition, although both strains have similar genes for

332 generating excretion products and both excrete formate, acetate, and succinate, M. alcaliphilum

$33320 \mathrm{Z}$ also produces $\mathrm{H}_{2}$, lactate, and hydroxybutyrate, while $M$. buryatense 5GB1 does not excrete

334 these compounds at detectable levels. Two different gamma-proteobacterial methanotrophs

335 isolated from a freshwater lake, Methylobacter tundripaludum 31/32 and Methylomonas sp.

336 LW13, show excretion profiles more similar to $M$. buryatense 5GB1 suggesting that $M$.

337 alcaliphilum $20 \mathrm{Z}$ regulates this metabolism differently from the other Type I methanotrophs

338 tested. The $\mathrm{O}_{2} / \mathrm{CH}_{4}$ ratio measured for $M$. buryatense 5GB1 under slower growth $\mathrm{O}_{2}$-limitation

339 (one-seventh of the maximum growth rate) is similar to that for faster growth $\mathrm{O}_{2}$-limitation (one-

340 half of the maximum growth rate), and in both cases, the results suggest a small amount of

341 respiration. One $\mathrm{O}_{2}$ is needed for each methane consumed, so any $\mathrm{O}_{2}$ utilized above a 1:1 ratio is

342 assumed to be used for respiration. The metabolic model constrained by the experimental 
$343 \mathrm{O}_{2} / \mathrm{CH}_{4}$ ratio predicts a significant fraction $(71 \% \pm 1 \%)$ of the ATP is generated by substrate

344 level phosphorylation, compared to $53 \% \pm 1 \%$ predicted with the unconstrained model.

345 Therefore, in M. buryatense 5GB1 grown at low growth rate under $\mathrm{O}_{2}$-limitation, the excreted

346 organic acids are not generated in a true fermentation metabolism, but in a mixed mode of

347 respiration and fermentation.

348

349 The aa3 cytochrome oxidase mutant strain shows a major defect in both growth rate and yield,

350 but carries out the same relative level of respiration as the wild-type in the $\mathrm{O}_{2}$-limited bioreactor.

351 The genome contains multiple alternative predicted terminal oxidases, and it is likely that one or

352 more of these is able to support respiration in the absence of the aa3 oxidase complex, albeit at

353 reduced growth rate and yield. Although the model predicted a higher growth rate for the aa3

354 cytochrome oxidase mutant strain than that observed in the experimental work, this likely

355 reflects either an inaccurate prediction of the bioenergetics of the alternative cytochrome

356 oxidases used in the aa3 cytochrome oxidase mutant strain, or insufficient activity of those

357 alternate enzymes in the cultures.

358

359 Our results show that although the genetic potential for a full fermentative metabolism exists in

360 M. buryatense 5GB1, this metabolic mode does not occur under the conditions tested. That result

361 suggests either that the full fermentative metabolism occurs under conditions not tested, or that

362 M. buryatense 5GB1 has not evolved to use a fermentation metabolism in response to low $\mathrm{O}_{2}$

363 availability or minimal ATP production from respiration. Further work is required to determine if

364 fermentation is commonly utilized by aerobic methanotrophs in their natural environments, and

365 if it can be reproduced in an industrial setting. 
367 Our results provide insights into the metabolism of formaldehyde and formate under low $\mathrm{O}_{2}$

368 conditions (Fig. 4). Methanol dehydrogenase generates formaldehyde from methanol (de la Torre

369 et al., 2016). In all of these experiments, no lanthanides were added, so the dominant methanol

370 dehydrogenase is the calcium-dependent MxaF-type enzyme, not the lanthanide-dependent

371 methanol dehydrogenase (Xox) (Chu et al., 2016). Formaldehyde is then consumed, with two

372 possible routes existing: 1) incorporation into the ribulose monophosphate cycle for assimilation

373 via hexulose phosphate synthase, and/or 2) oxidation to formate by the $\mathrm{H}_{4} \mathrm{MPT}$-dependent

374 pathway (de la Torre et al., 2016). It is possible to bypass formaldehyde oxidation completely,

375 using the cyclic ribulose monophosphate pathway for $\mathrm{CO}_{2}$ generation. M. buryatense 5GB1

376 contains two copies of genes encoding the key enzyme for that pathway, 6-phosphogluconate

377 dehydrogenase. Mutation of these genes, either singly or doubly, did not generate a significant

378 growth defect and did not change the excretion profile, suggesting that flux through this pathway

379 is minimal under the growth conditions tested. However, it was not possible to obtain null

380 mutants in genes of the $\mathrm{H}_{4} \mathrm{MPT}$ pathway, confirming the importance of this pathway in

381 methanotrophic metabolism in this bacterium, and confirming significant flux from

382 formaldehyde to formate.

383

384 Formate is the major excreted organic acid, and our results suggest that formate is excreted as a

385 result of oxidation of formaldehyde to formate at a higher flux than the oxidation of formate to

$386 \mathrm{CO}_{2}$. Regulation of formate excretion could occur at the level of export or formate

387 dehydrogenase activity. This conclusion is supported by our findings that when the major

388 formate consuming enzyme (formate dehydrogenase) is mutated, excreted formate increases 
389 more than 200 fold. When formate is excreted instead of being oxidized to $\mathrm{CO}_{2}$, it decreases the

390 amount of NADH formed (Fig. 4). The phenotype of the mutant in the major NADH consuming

391 reaction, NADH dehydrogenase, was similar to that of the formate dehydrogenase mutant,

392 suggesting the possibility that formate excretion could be linked to redox imbalance.

393

394 The severe growth defect of the aa3 oxidase mutant strain suggests that this terminal oxidase is

395 the major one under the growth conditions tested. When the terminal electron acceptor is

396 restricted, it would reduce the amount of NADH consumed, which might be predicted to

397 generate a redox imbalance. As noted above, excreting a portion of formate would avoid

398 generation of NADH from the oxidation of that formate to $\mathrm{CO}_{2}$, which might partially alleviate

399 redox imbalance.

400

401 M. buryatense 5GB1 contains genes for interconverting acetyl-CoA, acetyl-phosphate and

402 acetate and also for generating acetyl-phosphate via the XFP pathway, from xylulose-phosphate.

403 The latter pathway has been predicted to operate in M. buyatense 5GB1 (Henard et al., 2017).

404 Our results suggest that the excreted acetate is produced by a combination of the $A C K$ and $A C S$

405 pathways. The $x f p 1 / x f p 2$ double knockout has limited impact on the secretion of acetate,

406 suggesting the acetate production route was not interrupted in this strain. The unsuccessful

407 attempts to generate the ack/acs double mutant strain suggested that this interconversion between

408 acetyl-P, acetate, and acetylCoA may be essential for growth. The Xfp route would not generate

$409 \mathrm{NADH}$, compared to the route via pyruvate dehydrogenase, and it is possible that acetate

410 excretion is a second mechanism for managing redox balance. 
411 The insights obtained in this work have implications for consumption of methane in natural

412 communities. It has been shown that methane is consumed by a community of methanotrophic

413 and non-methanotrophic bacteria, with methanotrophs excreting carbon to support the non-

414 methanotrophic population (Radajewski et al., 2003; Oshkin et al., 2015). Recent coculture

415 studies have demonstrated that a major interaction occurs between a methanotroph and a non-

416 methanotrophic methylotroph isolated from a lake sediment methane consuming community

417 (Krause et al., 2017). In that study, under $\mathrm{O}_{2}$-limitation conditions similar to those in which

418 these bacteria exist in the lake sediment, the methanotroph was found to excrete methanol to

419 support the non-methanotrophic methylotroph (Krause et al., 2017). Similarly, methane-starved

420 cells of a marine methanotroph were found to excrete methanol upon recovery (Tavormina et al.,

421 2017). Our results suggest that under the $\mathrm{O}_{2}$-starvation conditions tested here, the methanotrophs

422 should also excrete formate and acetate, which would be expected to support a broader

423 population of non-methylotrophs such as those observed previously (Oshkin et al., 2015).

424 This work also suggests approaches for increasing excretion of specific compounds for

425 biotechnology applications. Our evidence is consistent with excretion of formate and acetate as

426 a mechanism to achieve redox balance. Correcting the imbalance is not as simple as decreasing

427 the NADH pool, since addition of lactate dehydrogenase to M. buryatense 5GB1C and

428 concomitant production of lactate at a level similar to acetate did not decrease formate + acetate

429 excretion as might be expected (Henard et al., 2016). Likely, it will be necessary to assess flux

430 through the entire metabolic network to determine network response under such conditions. The

431 first steps to measure metabolic flux in methanotrophs have now been reported (Fu et al., 2017),

432 suggesting this approach will soon be feasible as a tool for metabolic engineering. In addition, 
433 the updated metabolic model for M. buryatense 5GB1 reported here will provide a valuable

434 companion tool to effectively predict modifications that will lead to desired metabolic outcomes.

435

436 CONCLUSIONS

437 In summary, under the $\mathrm{O}_{2}$-starvation conditions tested in this study, M. buryatense 5GB1

438 maintains a metabolic state representing a hybrid metabolism of fermentation and respiration.

439 The phenotype of mutants with associated metabolic flux modeling suggested that secretion of

440 formate and acetate could be a response to redox imbalance.

441

442

SEQUENCE DATA

443 Normalized counts and computed pairwise fold changes for the RNA-seq experiments are

444 available in Table S1. All reads files (fastq-format) and per-gene read counts were submitted to

445 the Sequence Read Archive (SRA) and Gene Expression Omnibus (GEO), respectively, under

446 bioproject number PRJNA396065.

447

448 ACKNOWLEDGEMENTS

449 We would like to thank Alan Bohn for help in constructing the $n d h 2$ and $b h r$ mutants. This work

450 was facilitated through the use of advanced computational storage and networking

451 infrastructure provided by the Hyak supercomputer system supported in part by the University of

452 Washington eScience Institute.

453

454 REFERENCES

455 Anders S, Huber W. 2010. Differential expression analysis for sequence count data. Genome $456 \quad$ Biol 11:R106. 
457 Anders S, McCarthy DJ, Chen Y, Okoniewski M, Smyth GK, Huber W, Robinson MD. 2013.

458 Count-based differential expression analysis of RNA sequencing data using R and

459 Bioconductor. Nat Protoc 8:1765-1786.

460 Anders S, Pyl PT, Huber W. 2015. HTSeq--a Python framework to work with high-throughput

$461 \quad$ sequencing data. Bioinformatics 31:166-169.

462 Chen KH, Wu HH, Ke SF, Rao YT, Tu CM, Chen YP, Kuei KH, Chen YS, Wang VC, Kao WC,

463 Chan SI. 2012. Bacteriohemerythrin bolsters the activity of the particulate methane

464 monooxygenase (pMMO) in Methylococcus capsulatus (Bath). J Inorg Biochem 111:10-7.

465 Chistoserdova L. 2015. Methylotrophs in natural habitats: current insights through metagenomics.

466 Applied Microbiology and Biotechnology 99(14):5763-5779.

467 Chu F, Lidstrom ME. 2016. XoxF acts as the predominant methanol dehydrogenase in the type I

468 methanotroph Methylomicrobium buryatense. J Bacteriol 198:1317-25.

469 de la Torre A, Metivier A, Chu F, Laurens LML, Beck DA, Pienkos PT, Lidstrom ME and

470 Kalyuzhnaya MG. 2015. Genome-scale metabolic reconstructions and theoretical

471 investigation of methane conversion in Methylomicrobium buryatense strain 5G(B1).

$472 \quad$ Microb. Cell Fact. 14:188.

473 Ebrahim A, Lerman JA, Palsson BO, Hyduke DR. 2013. COBRApy: COnstraints-based

$474 \quad$ reconstruction and analysis for Python. BMC Syst Biol. 8:7:74.

475 Fu Y, Li Y, Lidstrom ME. 2017. The oxidative TCA cycle operates during methanotrophic

476 growth of the Type I methanotroph Methylomicrobium buryatense 5GB1. Metab Eng.

$477 \quad 42: 43-51$

478 Gibson DG, Young L, Chuang RY, Venter JC, Hutchison CA, Smith HO. 2009. Enzymatic

479 assembly of DNA molecules up to several hundred kilobases. Nat Methods 6(5): 343-345. 
480 Gilman A, Laurens LL, Puri AW, Chu F, Pienkos PT, and Lidstrom ME. 2015. Bioreactor

481 performance parameters for an industrially-promising methanotroph Methylomicrobium

482 buryatense 5GB1. Microb. Cell Fact. 14, 182.

483 Henard CA, Smith H, Dowe N, Kalyuzhnaya MG, Pienkos PT, Guarnieri MT. 2016.

484 Bioconversion of methane to lactate by an obligate methanotrophic bacterium. Sci Rep.

$485 \quad 6: 21585$.

486 Henard CA, Smith HK, Guarnieri MT. 2017. Phosphoketolase overexpression increases biomass

487 and lipid yield from methane in an obligate methanotrophic biocatalyst. Metab Eng. 41:152-

$488 \quad 158$.

489 Kaluzhnaya M, Khmelenina V, Eshinimaev B, Suzina N, Nikitin D, Solonin A, Lin J-L,

490 McDonald I, Murrell C, Trotsenko Y. 2001. Taxonomic characterization of new alkaliphilic

491 and alkalitolerant methanotrophs from soda lakes of the Southeastern Transbaikal region and

492 description of Methylomicrobium buryatense sp. nov. Systematic and Applied Microbiology

$493 \quad 24: 166-176$.

494 Kalyuzhnaya MG, Lamb AE, McTaggart TL, Oshkin IY, Shapiro N, Woyke T, Chistoserdova L.

495 2015b. Draft genome sequences of gammaproteobacterial methanotrophs isolated from Lake

496 Washington sediment. Genome Announc. 12:3(2).

497 Kalyuzhnaya MG, Yang S, Rozova ON, Smalley NE, Clubb J, Lamb A, Gowda GAN, Raftery D,

498 Fu Y, Bringel F. 2013. Highly efficient methane biocatalysis revealed in a methanotrophic

$499 \quad$ bacterium. Nature Communications 4:2785.

500 Kalyuzhnaya MG, Puri AW, Lidstrom ME. 2015a. Metabolic engineering in methanotrophic

$501 \quad$ bacteria. Metab. Eng. 29, 142-52. 
502 Khmelenina V, Beck DA, Munk C, Davenport K, Daligault H, Erkkila T, Goodwin L, Gu W, Lo

503 CC, Scholz M, Teshima H, Xu Y, Chain P, Bringel F, Vuilleumier S, Dispirito A, Dunfield

504 P, Jetten MS, Klotz MG, Knief C, Murrell JC, Op den Camp HJ, Sakai Y, Semrau J,

505 Svenning M, Stein LY, Trotsenko YA, Kalyuzhnaya MG. 2013. Draft genome sequence of

506 Methylomicrobium buryatense strain 5G, a haloalkaline-tolerant methanotrophic bacterium.

$507 \quad$ Genome Announc. 1, e00053-13.

508 Knief C. 2015. Diversity and habitat preferences of cultivated and uncultivated aerobic

509 methanotrophic bacteria evaluated based on pmoA as molecular marker. Frontiers in

$510 \quad$ Microbiology 6:1346.

511 Krause S, Johnson S, Karunaratne Y, Fu Y, Beck DA, Chistoserdova L, Lidstrom ME.

512 Lanthanide-dependent cross-feeding of methane derived carbon is linked by microbial

513 community interactions. Proc Natl Acad Sci 114:358-63.

514 Li H, Durbin R. 2010. Fast and accurate long-read alignment with Burrows-Wheeler transform.

515 Bioinformatics 26:589-595.

516 Li H, Handsaker B, Wysoker A, Fennell T, Ruan J, Homer N, Marth G, Abecasis G, Durbin R,

517 Genome Project Data Processing S. 2009. The Sequence Alignment/Map format and

518 SAMtools. Bioinformatics 25:2078-2079.

519 Markowitz VM, Chen IM, Palaniappan K, Chu K, Szeto E, Pillay M, Ratner A, Huang J, Woyke

520 T, Huntemann M, Anderson I, Billis K, Varghese N, Mavromatis K, Pati A, Ivanova NN,

521 Kyrpides NC. 2014. IMG 4 version of the integrated microbial genomes comparative

522 analysis system. Nucleic Acids Res 42:D560-567.

523 Oshkin IY, Beck DA, Lamb AE, Tchesnokova V, Benuska G, McTaggart TL, Kalyuzhnaya MG, 524 Dedysh SN, Lidstrom ME, Chistoserdova L. 2015. Methane-fed microbial microcosms 
show differential community dynamics and pinpoint taxa involved in communal response. ISME J. 9(5):1119-29.

527 Puri AW, Owen S, Chu F, Chavkin T, Beck DA, Kalyuzhnaya MG, Lidstrom ME. 2015. Genetic

528 tools for the industrially promising methanotroph Methylomicrobium buryatense. Appl.

529 Environ. Microbiol. 81:1775-81.

530 Puri AW, Schaefer AL, Fu Y, Beck DA, Greenberg EP, Lidstrom ME. 2017. Quorum sensing in 531 a methane-oxidizing bacterium. J. Bacteriol. 199(5): e00773-16.

532 Radajewski S, McDonald IR, Murrell JC. 2003. Stable-isotope probing of nucleic acids: a 533 window to the function of uncultured microorganisms. Curr Opin Biotechnol. 14(3):296-302.

534 Ruff SE, Biddle JF, Teske AP, Knittel K, Boetius, A, Ramette, A. 2015 Global dispersion and 535 local diversification of the methane seep microbiome. Proc Natl Acad Sci USA 112(13):4015-4020.

537 Tavormina PL, Kellermann MY, Antony CP, Tocheva EI, Dalleska NF, Jensen AJ, Valentine

538 DL2, Hinrichs KU, Jensen GJ, Dubilier N, Orphan VJ. 2107. Starvation and recovery in the 539 deep-sea methanotroph Methyloprofundus sedimenti. Mol Microbiol. 103(2):242-252.

540 Whittenbury R, Phillips KC, and Wilkinson JF. 1970. Enrichment, isolation and some properties 541 of methane-utilizing bacteria. Journal of General Microbiology 61:205-218

542 Yan X, Chu F, Puri AW, Fu Y, Lidstrom, ME. 2016. Electroporation-based genetic manipulation 543 in type i methanotrophs. Appl. Environ. Microbiol. 82:2062-2069.

\section{FIGURE LEGENDS}

546 Figure 1. Predicted pathways for generation of excreted products in M. buryatense 5GB1.

547 Enzymes and gene designations are listed. 
549 Figure 2. Excreted products for M. buryatense 5GB1 (WT) and the aa3 cytochrome oxidase

550 mutant $(\Delta$ cytaa3 $)$ in $\mathrm{O}_{2}$-limited vial and bioreactor cultures, for $M$. buryatense 5GB1C mutants in

551 NADH dehydrogenase $2(\Delta \mathrm{ndh} 2)$, molybdenum-containing formate dehydrogenase $\left(\Delta \mathrm{fdh} \_\mathrm{Mo}\right)$,

552 and a double mutant in the phosphoketolase homologs $(\Delta x f p 12)$ in $\mathrm{O}_{2}$-limited vial cultures, and

553 for Methylomonas sp. LW13 (LW13) and Methylobacter tundripaludum 31/32 (3132) in $\mathrm{O}_{2-}$

554 limited vial cultures. Lactate and hydroxybutyrate were not detected. $\mathrm{H}_{2}$ was tested in the wild-

555 type M. buryatense, and was not detected.

556

557 Figure 3 . Steady state ${ }^{13} \mathrm{C}$ tracer analysis of the aa3 cytochrome oxidase mutant strain. A)

558 Metabolic subnetwork that could be deciphered using steady state ${ }^{13} \mathrm{C}$ tracer analysis. Pathways

559 with dashed line indicate multiple reactions combined into one reaction. Labeling pattern of

560 metabolites in bold are measured using LC-MS/MS. TCA cycle contributes $45 \%$ of total influx

561 into malate de novo synthesis, similar to WT. B) Labeling patterns of malate and threonine

562 (reflecting OAA) of the aa3 mutant strain showing different carboxylation signature.

563

564 Figure 4. Summary of central metabolism in M. buryatense 5GB1. GAP, glyceraldehyde- 3-P;

565 KDPG, 2-keto-3-deoxy-6-P-gluconate; BPGA, 1,3-bisP-glycerate; PGA, 3-P-glycerate and 2-P-

566 glycerate; PEP, phosphoenolpyruvate. Mutants with growth and excretion phenotypes in bold;

567 those with excretion phenotypes only, in italics. 


\section{Table $\mathbf{1}$ (on next page)}

Oxygen-limited metabolism in the methanotroph Methylomicrobium buryatense 5GB1C Bioreactor data summary. 
1 Table 1. Bioreactor data summary.

\begin{tabular}{|c|c|c|c|c|}
\hline Experiment ID & FM86 & FM87 & FM88 & FM90 \\
\hline Strain & 5GB1 WT & 5GB1 WT & 5GB1 $\Delta$ Cyt aa3 & 5GB1 $\Delta$ Cyt aa3 \\
\hline Dilution Rate $\left(\mathrm{h}^{-1}\right)$ or Growth Rate & 0.036 & 0.035 & 0.034 & 0.035 \\
\hline Cell Density (gCDW L-1 $)$ & 0.32 & 0.28 & 0.25 & 0.21 \\
\hline Dissolved Oxygen $\left(\mathrm{mg} \mathrm{L}^{-1}\right)$ & 0.22 & 0.25 & 0.25 & 0.26 \\
\hline Oxygen Uptake $\left(\mathrm{mmol} \mathrm{h}^{-1}\right)$ & 0.92 & 0.94 & 0.95 & 0.94 \\
\hline Methane Uptake $\left(\mathrm{mmol} \mathrm{h}^{-1}\right)$ & 0.86 & 0.88 & 0.88 & 0.89 \\
\hline Specific Oxygen Uptake (mmol gCDW-1 $\left.\mathrm{h}^{-1}\right)$ & 2.9 & 3.1 & 3.9 & 4.5 \\
\hline Specific Methane Uptake $\left(\mathrm{mmol} \mathrm{gCDW}^{-1} \mathrm{~h}^{-1}\right)$ & 2.7 & 2.9 & 3.6 & 4.2 \\
\hline $\mathrm{O}_{2} / \mathrm{CH}_{4}$ Uptake Ratio & 1.1 & 1.1 & 1.1 & 1.1 \\
\hline Inlet Gas Composition & $\begin{array}{c}20 \% \mathrm{CH}_{4}, 5 \% \mathrm{O}_{2} \\
75 \% \mathrm{~N}_{2} \\
\end{array}$ & $\begin{array}{c}20 \% \mathrm{CH}_{4}, 5 \% \mathrm{O}_{2} \\
75 \% \mathrm{~N}_{2} \\
\end{array}$ & $\begin{array}{c}20 \% \mathrm{CH}_{4}, 5 \% \mathrm{O}_{2} \\
75 \% \mathrm{~N}_{2} \\
\end{array}$ & $\begin{array}{c}20 \% \mathrm{CH}_{4}, 5 \% \mathrm{O}_{2} \\
75 \% \mathrm{~N}_{2} \\
\end{array}$ \\
\hline Formate $(\mu \mathrm{mol}$ gCDW- 1$)$ & 479.1 & 203.1 & 1216.3 & 2995.2 \\
\hline Acetate $\left(\mu \mathrm{mol} \mathrm{gCDW}^{-1}\right)$ & 30.2 & 39.2 & 85.7 & 81.0 \\
\hline
\end{tabular}




\section{Table 2 (on next page)}

RNAseq analysis of genes involved in genes predicted to have a potential role in fermentation metabolism (see Table 3). 
1 Table 2. RNAseq analysis of genes involved in genes predicted to have a potential role in fermentation metabolism (see Table 3).

\begin{tabular}{|c|c|c|c|c|c|c|c|c|c|c|}
\hline \multicolumn{3}{|c|}{ Conditions } & \multicolumn{2}{|c|}{$\begin{array}{l}\text { Slow growth } 02- \\
\text { limited vs. fast } \\
\text { growth } 02 \text {-limited }\end{array}$} & \multicolumn{2}{|c|}{$\begin{array}{l}\text { Slow growth } 02- \\
\text { limited vs. fast } \\
\text { growth } \mathrm{CH} 4 \text {-limited }\end{array}$} & \multicolumn{2}{|c|}{$\begin{array}{l}\text { Fast growth } 02- \\
\text { limited vs. fast } \\
\text { growth } \mathrm{CH} 4 \text {-limited }\end{array}$} & \multicolumn{2}{|c|}{$\begin{array}{l}\text { Cytochrome oxidase } \\
\text { aa3 vs. WT (both slow } \\
\text { growth 02-limited) }\end{array}$} \\
\hline Gene & Enzyme & Locus tag & Fold change & $\begin{array}{l}\text { Adjusted } p \\
\text { values }\end{array}$ & Fold change & $\begin{array}{l}\text { Adjusted } p \\
\text { values }\end{array}$ & $\begin{array}{c}\text { Fold } \\
\text { change }\end{array}$ & $\begin{array}{l}\text { Adjusted } \\
\text { p values }\end{array}$ & Fold change & $\begin{array}{l}\text { Adjusted } p \\
\text { values }\end{array}$ \\
\hline$x f p 1$ & phospho-ketolase & METBUDRAFT_1551 & 2.1 & 0.031 & 1.6 & 0.258 & 0.7 & 0.013 & 1.7 & 0.219 \\
\hline$x f p 2$ & phospho-ketolase & METBUDRAFT_0185 & 1.3 & 0.404 & 1.3 & 0.478 & 1 & 0.904 & 1.1 & 0.997 \\
\hline ack & acetate kinase & METBUDRAFT_1552 & 0.9 & 0.674 & 0.8 & 0.65 & 1 & 0.839 & 1.2 & 0.948 \\
\hline acs & $\begin{array}{l}\text { acetylCoA } \\
\text { synthase }\end{array}$ & METBUDRAFT_1565 & 1.6 & 0.141 & 1.3 & 0.516 & 0.8 & 0.227 & 1.2 & 0.902 \\
\hline pta & $\begin{array}{l}\text { phosphotrans- } \\
\text { acetylase }\end{array}$ & METBUDRAFT_1957 & 1.1 & 0.819 & 1.1 & 0.802 & 1 & 0.837 & 1 & 1 \\
\hline Idh & $\begin{array}{c}\text { lactate } \\
\text { dehydrogenase }\end{array}$ & METBUDRAFT_3726 & 1 & 0.95 & 0.8 & 0.665 & 0.9 & 0.33 & 1 & 1 \\
\hline$m d h$ & $\begin{array}{c}\text { malate } \\
\text { dehydrogenase }\end{array}$ & METBUDRAFT_2208 & 1 & 0.934 & 0.9 & 0.862 & 1 & 0.825 & 1.1 & 0.997 \\
\hline $\begin{array}{l}\text { Malic } \\
\text { enzyme }\end{array}$ & malic enzyme & METBUDRAFT_2185 & 1 & 0.916 & 1 & 0.918 & 0.9 & 0.584 & 1.1 & 0.997 \\
\hline \multirow{4}{*}{ hox } & \multirow{4}{*}{ hydrogenase } & METBUDRAFT_1387 & 2.6 & $1.0 \mathrm{E}-04$ & 1.5 & 0.181 & 0.6 & $2.5 \mathrm{E}-05$ & 1.5 & 0.422 \\
\hline & & METBUDRAFT_1388 & 2 & 0.01 & 1.4 & 0.364 & 0.7 & 0.004 & 1.5 & 0.51 \\
\hline & & METBUDRAFT_1389 & 1.9 & 0.021 & 1.5 & 0.258 & 0.8 & 0.07 & 1.3 & 0.858 \\
\hline & & METBUDRAFT_1390 & 1.5 & 0.206 & 1.5 & 0.255 & 1 & 0.866 & 1.2 & 0.901 \\
\hline$n d h 1$ & $\begin{array}{c}\mathrm{NADH} \\
\text { dehydrogenase }\end{array}$ & METBUDRAFT_1319 & 1.2 & 0.534 & 1.3 & 0.556 & 1 & 0.871 & 1.1 & 0.997 \\
\hline
\end{tabular}




\begin{tabular}{|c|c|c|c|c|c|c|c|c|c|c|}
\hline$n d h 2 a$ & $\begin{array}{c}\text { NADH } \\
\text { dehydrogenase }\end{array}$ & METBUDRAFT_2827 & 0.5 & 0.03 & 0.6 & 0.091 & 1.2 & 0.45 & 1.2 & 0.907 \\
\hline$n d h 2 b$ & & METBUDRAFT_2828 & 0.6 & 0.175 & 0.9 & 0.785 & 1.4 & 0.139 & 1.2 & 0.898 \\
\hline petA & bc1 complex & METBUDRAFT_2502 & 1.4 & 0.33 & 1.2 & 0.755 & 0.8 & 0.385 & 1.3 & 0.794 \\
\hline petB & & METBUDRAFT_2503 & 1.7 & 0.147 & 1.4 & 0.401 & 0.8 & 0.358 & 1.4 & 0.678 \\
\hline petC & & METBUDRAFT_2504 & 1.6 & 0.138 & 1.3 & 0.555 & 0.8 & 0.128 & 1.2 & 0.919 \\
\hline$c t a C$ & $\begin{array}{c}\text { cytochrome } \\
\text { oxidase (aa3-type) }\end{array}$ & METBUDRAFT_0311 & 1.9 & 0.044 & 2.1 & 0.011 & 1.1 & 0.501 & (deleted) & \\
\hline $\operatorname{ctaD}$ & & METBUDRAFT_0312 & 1.5 & 0.317 & 1.8 & 0.1 & 1.2 & 0.207 & (deleted) & \\
\hline $\operatorname{cta} G$ & & METBUDRAFT_0313 & 1.4 & 0.129 & 1.4 & 0.201 & 1 & 0.978 & $\begin{array}{l}\text { (very low } \\
\text { expression) }\end{array}$ & 3.57 E-09 \\
\hline $\operatorname{cta} E$ & & METBUDRAFT_0314 & 1.1 & 0.786 & 1.1 & 0.92 & 0.9 & 0.791 & $\begin{array}{l}\text { (very low } \\
\text { expression) }\end{array}$ & $1.57 \mathrm{E}-07$ \\
\hline$c b a A$ & $\begin{array}{l}\text { cytochrome } \\
\text { oxidase (ba3- } \\
\text { type) }\end{array}$ & METBUDRAFT_1311 & 1.4 & 0.24 & 2.1 & 0.005 & 1.5 & 0.001 & 1.3 & 0.856 \\
\hline$c b a B$ & & METBUDRAFT_1312 & 1.4 & 0.302 & 2.1 & 0.011 & 1.5 & 0.002 & 1.3 & 0.858 \\
\hline$c b a D$ & & METBUDRAFT_1313 & 1.3 & 0.358 & 2.1 & 0.005 & 1.5 & 0.001 & 1.1 & 0.997 \\
\hline gnd1 & $\begin{array}{c}6- \\
\text { phosphogluconate } \\
\text { dehydrogenase } \\
\text { (NADP) }\end{array}$ & METBUDRAFT_3313 & 1.6 & 0.04 & 1.5 & 0.118 & 0.9 & 0.693 & 1.5 & 0.431 \\
\hline gnd2 & $\begin{array}{c}6- \\
\text { phosphogluconate } \\
\text { dehydrogenase } \\
\text { (NAD) }\end{array}$ & METBUDRAFT_3982 & 0.9 & 0.674 & 1.1 & 0.847 & 1.3 & 0.089 & 0.9 & 0.997 \\
\hline
\end{tabular}




\begin{tabular}{|c|c|c|c|c|c|c|c|c|c|c|}
\hline$m t d 1$ & $\begin{array}{c}\text { methylene H4MPT } \\
\text { dehydrogenase }\end{array}$ & METBUDRAFT_1893 & 1.3 & 0.306 & 1.3 & 0.496 & 1 & 0.811 & 1.2 & 0.997 \\
\hline$m t d 2$ & $\begin{array}{c}\text { methylene H4MPT } \\
\text { dehydrogenase }\end{array}$ & METBUDRAFT_1894 & 1.1 & 0.821 & 1.1 & 0.855 & 1 & 0.95 & 1.1 & 0.997 \\
\hline fdh1a & $\begin{array}{c}\text { formate } \\
\text { dehydrogenase } \\
\text { (tungsten) }\end{array}$ & METBUDRAFT_0831 & 0.7 & 0.22 & 0.6 & 0.103 & 0.9 & 0.67 & 1.2 & 0.997 \\
\hline$f d h 1 b$ & & METBUDRAFT_0832 & 0.6 & 0.224 & 0.6 & 0.163 & 1 & 0.977 & 1.3 & 0.728 \\
\hline$f d h 2 a$ & $\begin{array}{c}\text { formate } \\
\text { dehydrogenase } \\
\text { (molybdenum) }\end{array}$ & METBUDRAFT_2829 & 0.9 & 0.912 & 0.9 & 0.868 & 1 & 0.874 & 1.1 & 0.997 \\
\hline$f d h 2 b$ & & METBUDRAFT_2830 & 0.8 & 0.315 & 0.7 & 0.17 & 0.9 & 0.485 & 1.1 & 0.997 \\
\hline$f d h 2 c$ & & METBUDRAFT_2831 & 1.5 & 0.115 & 0.8 & 0.4 & 0.5 & $1.64 \mathrm{E}-06$ & 1.2 & 0.989 \\
\hline$b h r$ & $\begin{array}{c}\text { Bacterio- } \\
\text { hemerythrin }\end{array}$ & METBUDRAFT_0310 & 9.9 & $1.39 \mathrm{E}-11$ & 391.4 & 1.96 E-198 & 2.2 & 0.001 & 1.2 & 0.883 \\
\hline
\end{tabular}

2 


\section{Table 3 (on next page)}

M. buryatense 5GB1C mutant characteristics; bold-face = mutants with phenotypes; italics $=$ no null mutants obtained 
Table 3. M. buryatense 5GB1C mutant characteristics; bold-face = mutants with phenotypes; italics $=$ no null mutants obtained

\begin{tabular}{|c|c|c|c|c|}
\hline Gene(s) deleted & Enzyme & Locus tag(s) & Phenotypes & Category \\
\hline ack & acetate kinase & METBUDRAFT_1552 & none & fermentation product: acetate \\
\hline acs & acetylCoA synthase & METBUDRAFT_1565 & none & fermentation product: acetate \\
\hline ack/acs & $\begin{array}{l}\text { acetate kinase/acety/CoA } \\
\text { synthase (double) }\end{array}$ & $\begin{array}{l}\text { METBUDRAFT_1552/ } \\
\text { METBUDRAFT_1565 }\end{array}$ & no null mutants & fermentation product: acetate \\
\hline pta & phosphotransacetylase & METBUDRAFT_1957 & none & fermentation product: acetate \\
\hline$x f p 1$ & phosphoketolase & METBUDRAFT_1551 & none & fermentation product: acetate \\
\hline$x f p 2$ & phosphoketolase & METBUDRAFT_0185 & none & fermentation product: acetate \\
\hline$x f p 1 / x f p 2$ & phosphoketolase (double) & $\begin{array}{l}\text { METBUDRAFT_1551/ } \\
\text { METBUDRAFT_0185 }\end{array}$ & none & fermentation product: acetate \\
\hline$I d h$ & lactate dehydrogenase & METBUDRAFT_3726 & none & fermentation product: lactate \\
\hline$m d h$ & malate dehydrogenase & METBUDRAFT_2208 & none & fermentation product: succinate \\
\hline malic_enzyme & malic enzyme & METBUDRAFT_2185 & none & fermentation product: succinate \\
\hline hox & hydrogenase & METBUDRAFT_1387-1390 & none & fermentation product: $\mathrm{H}_{2}$ \\
\hline$n d h 1$ & NADH dehydrogenase & METBUDRAFT_1319 & none & NADH utilization \\
\hline ndh2 & NADH dehydrogenase & METBUDRAFT_2827 & $\begin{array}{l}\text { formate up; acetate } \\
\text { and succinate down }\end{array}$ & NADH utilization \\
\hline ndh1/ndh2 & $\begin{array}{l}\text { NADH dehydrogenase } \\
\text { (double) }\end{array}$ & $\begin{array}{l}\text { METBUDRAFT_1319/ } \\
\text { METBUDRAFT_2827 }\end{array}$ & $\begin{array}{l}\text { formate up, acetate } \\
\text { and succinate down }\end{array}$ & NADH utilization \\
\hline pet $A B C$ & bc1 complex & METBUDRAFT_2502-2504 & none & NADH utilization \\
\hline ctaCD & $\begin{array}{l}\text { cytochrome oxidase aa3- } \\
\text { type }\end{array}$ & METBUDRAFT_0311-0312 & $\begin{array}{l}\text { formate up; acetate } \\
\text { and succinate down; } \\
\text { growth rate down }\end{array}$ & NADH utilization \\
\hline
\end{tabular}




\begin{tabular}{|c|c|c|c|c|}
\hline$c b a$ & $\begin{array}{l}\text { cytochrome oxidase cba- } \\
\text { type }\end{array}$ & METBUDRAFT_1311-1313 & none & NADH utilization \\
\hline gnd1 & $\begin{array}{l}\text { 6-phosphogluconate } \\
\text { dehydrogenase (NADP) }\end{array}$ & METBUDRAFT_3313 & none & NADH generation \\
\hline gnd2 & $\begin{array}{l}\text { 6-phosphogluconate } \\
\text { dehydrogenase (NAD) }\end{array}$ & METBUDRAFT_3982 & none & NADH generation \\
\hline gnd1/gnd2 & 6PGDH (double) & $\begin{array}{l}\text { METBUDRAFT_3313/METBUDR } \\
\text { AFT_3982 }\end{array}$ & none & NADH generation \\
\hline$m t d 1$ & $\begin{array}{l}\text { methylene H4MPT } \\
\text { dehydrogenase }\end{array}$ & METBUDRAFT_1893 & no null mutants & NADH generation \\
\hline$m t d 2$ & $\begin{array}{l}\text { methylene H4MPT } \\
\text { dehydrogenase }\end{array}$ & METBUDRAFT_1894 & no null mutants & NADH generation \\
\hline$f d h 1 a b$ & $\begin{array}{l}\text { formate dehydrogenase } \\
\text { (tungsten) }\end{array}$ & METBUDRAFT_0831-0832 & none & NADH generation \\
\hline fdh2 & $\begin{array}{l}\text { formate dehydrogenase } \\
\text { (molybdenum) }\end{array}$ & METBUDRAFT_2831 & $\begin{array}{l}\text { formate up; acetate } \\
\text { and succinate down }\end{array}$ & NADH generation \\
\hline$f d h 1 / f d h 2$ & $\begin{array}{l}\text { formate dehydrogenase } \\
\text { double }\end{array}$ & $\begin{array}{l}\text { METBUDRAFT_0831- } \\
\text { 0832/METBUDRAFT_2831 }\end{array}$ & $\begin{array}{l}\text { formate up; acetate } \\
\text { and succinate down; } \\
\text { growth rate down }\end{array}$ & NADH generation \\
\hline$b h r$ & bacteriohemerythrin & METBUDRAFT_0310 & none & $\mathrm{O}_{2}$ starvation \\
\hline
\end{tabular}




\section{Table 4(on next page)}

Flux balance analysis results 
1 Table 4. Modeling results

\begin{tabular}{|c|c|c|c|c|}
\hline Experiment ID & FM86 & FM87 & FM88 & FM90 \\
\hline Strain & $5 \mathrm{~GB} 1 \mathrm{WT}$ & 5GB1 WT & $5 G B 1 \Delta C y t$ aa3 & 5GB1 $\Delta$ Cyt aa3 \\
\hline Experimental growth rate $\left(\mathrm{h}^{-1}\right)$ & 0.036 & 0.035 & 0.034 & 0.035 \\
\hline $\begin{array}{l}\text { Growth rate from simulation case } 1 \text { (specific methane uptake } \\
\text { rate constraint) }\end{array}$ & 0.04 & 0.043 & NA & NA \\
\hline $\begin{array}{l}\text { Growth rate from simulation case2 (adding } \mathrm{O}_{2} \text { uptake rate } \\
\text { constraint to case } 1 \text { ) }\end{array}$ & 0.034 & 0.036 & NA & NA \\
\hline $\begin{array}{l}\text { Growth rate from simulation case3 (adding secreted products } \\
\text { constraints to case 2) }\end{array}$ & 0.033 & 0.034 & NA & NA \\
\hline $\begin{array}{l}\text { Growth rate from simulation case } 4 \text { ( } \Delta \text { Cyt aa3 with methane, } \mathrm{O}_{2} \\
\text { uptake rate and secreted products constraint) }\end{array}$ & NA & NA & 0.043 & 0.048 \\
\hline
\end{tabular}

2 


\section{Figure 1 (on next page)}

Predicted pathways for generation of excreted products in M. buryatense 5GB1.

Enzymes and gene designations are listed. 


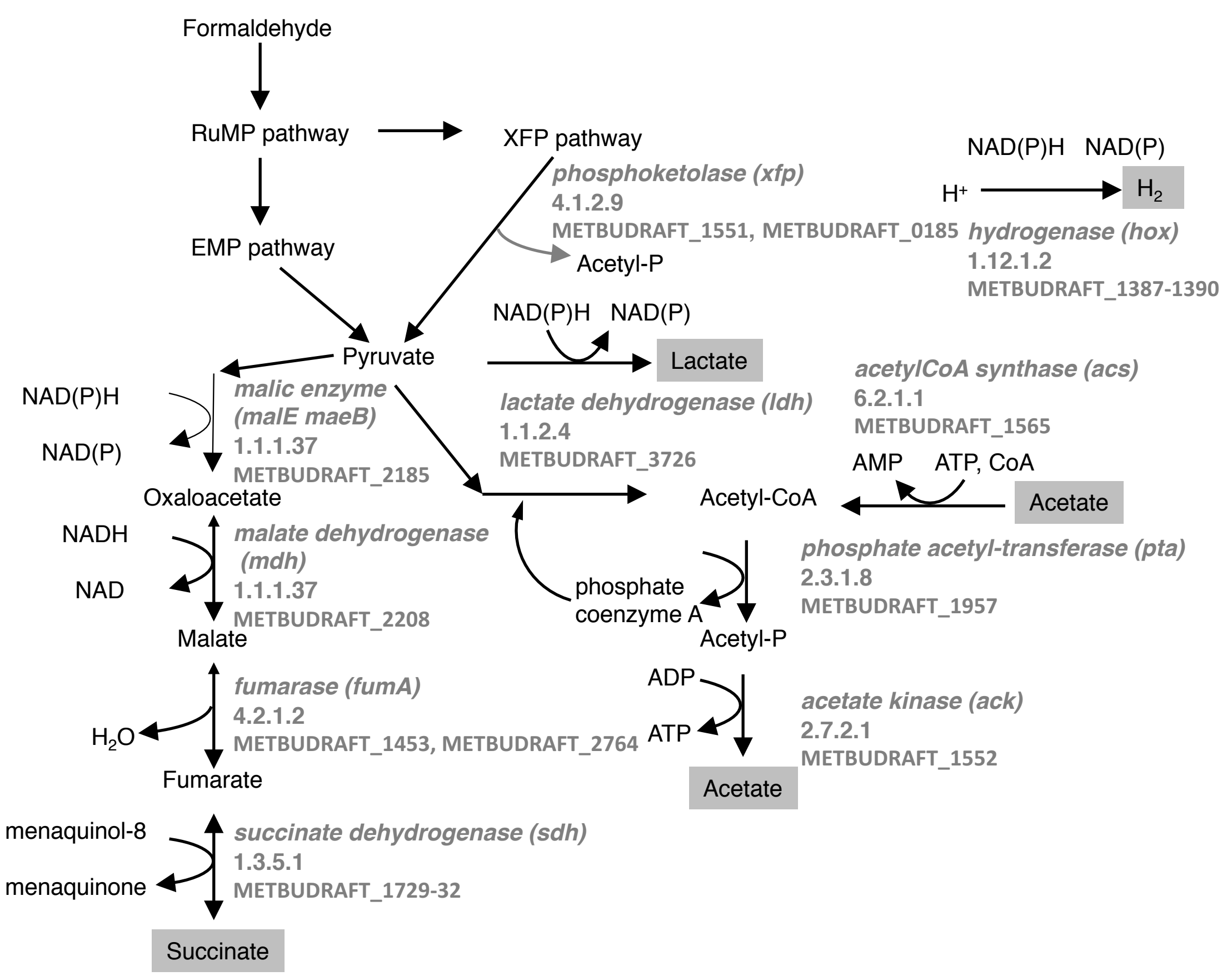


Figure 2 (on next page)

Excreted products profile

Excreted products profile for $M$. buryatense 5GB1 (WT) and the aa3 cytochrome oxidase mutant ( $\triangle$ cytaa3) in $\mathrm{O}_{2}$-limited vial and bioreactor cultures, for $M$. buryatense $5 \mathrm{GB1C}$ mutants in NADH dehydrogenase 2 ( $\triangle \mathrm{ndh} 2$ ), molybdenum-containing formate dehydrogenase ( $\left.\Delta \mathrm{fdh} \_\mathrm{Mo}\right)$, and a double mutant in the phosphoketolase homologs ( $\left.\Delta \mathrm{xfp} 12\right)$ in $\mathrm{O}_{2}$-limited vial cultures, and for Methylomonas sp. LW13 (LW13) and Methylobacter tundripaludum 31/32 (3132) in $\mathrm{O}_{2}$-limited vial cultures. Lactate and hydroxybutyrate were not detected. $\mathrm{H}_{2}$ was tested in the wild-type M. buryatense, and was not detected. 


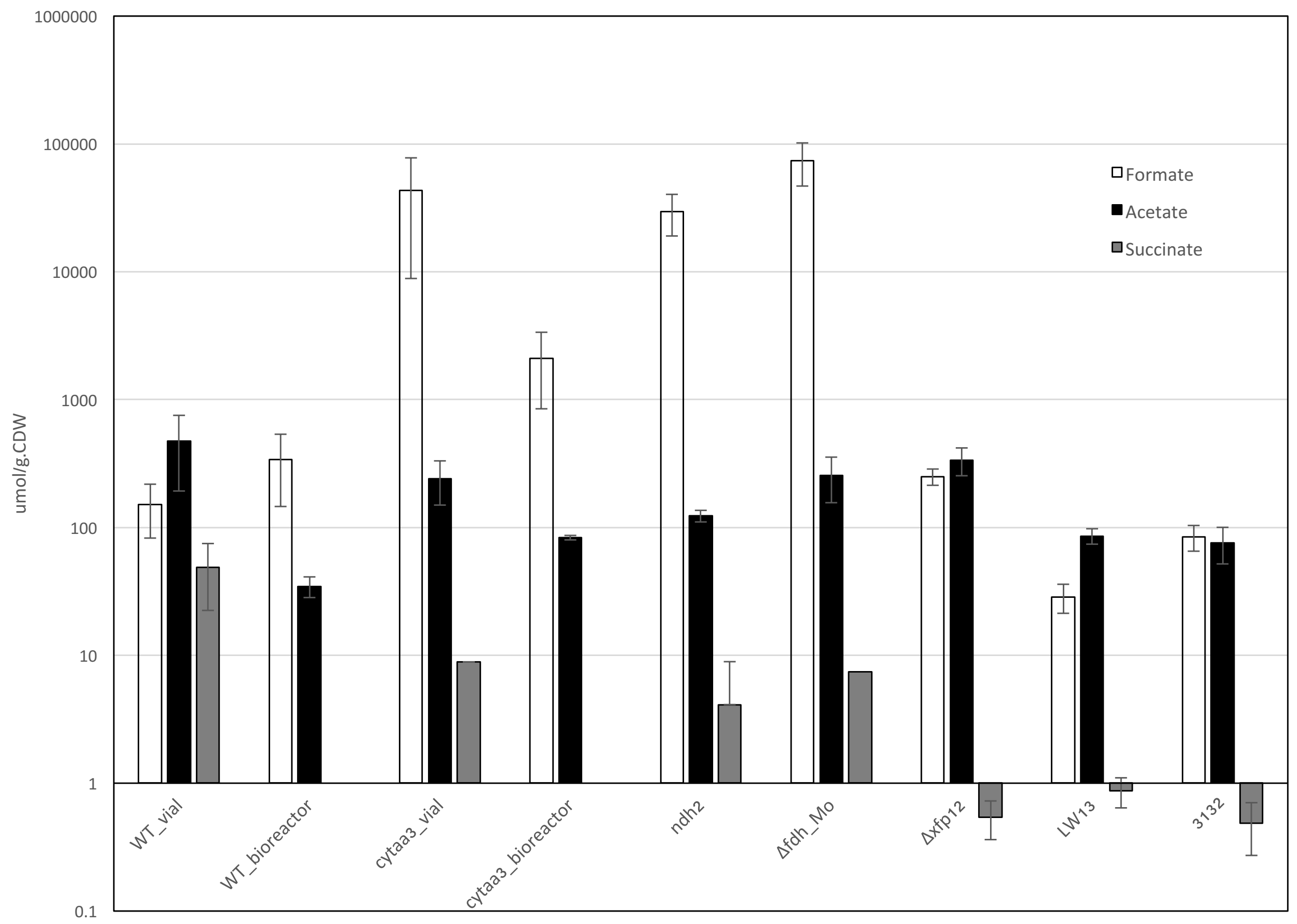


Figure 3 (on next page)

Steady state $13 \mathrm{C}$ tracer analysis of the aa3 cytochrome oxidase mutant strain.

A) Metabolic subnetwork that could be deciphered using steady state ${ }^{13} \mathrm{C}$ tracer analysis.

Pathways with dashed line indicate multiple reactions combined into one reaction. Labeling pattern of metabolites in bold are measured using LC-MS/MS. TCA cycle contributes $45 \%$ of total influx into malate de novo synthesis, similar to WT. B) Labeling patterns of malate and threonine (reflecting OAA) of the aa3 mutant strain showing different carboxylation signature. 
A

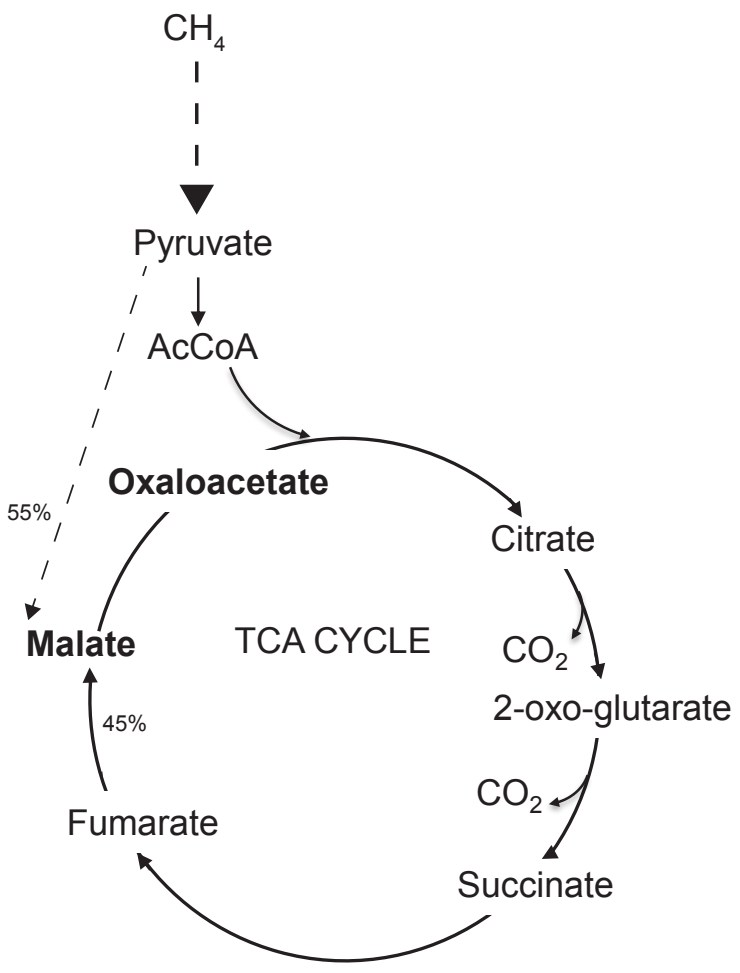

B

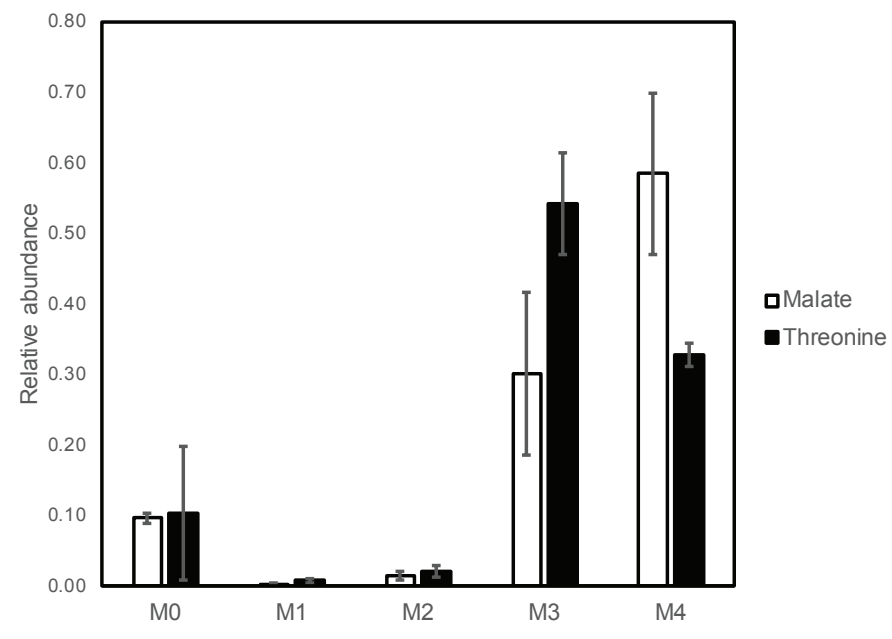




\section{Figure 4 (on next page)}

Summary of central metabolism in M. buryatense 5GB1.

GAP, glyceraldehyde- 3-P; KDPG, 2-keto-3-deoxy-6-P-gluconate; BPGA, 1,3-bisP-glycerate; PGA, 3-P-glycerate and 2-P-glycerate; PEP, phosphoenolpyruvate. Mutants with growth and excretion phenotypes in bold; those with excretion phenotypes only, in italics. 


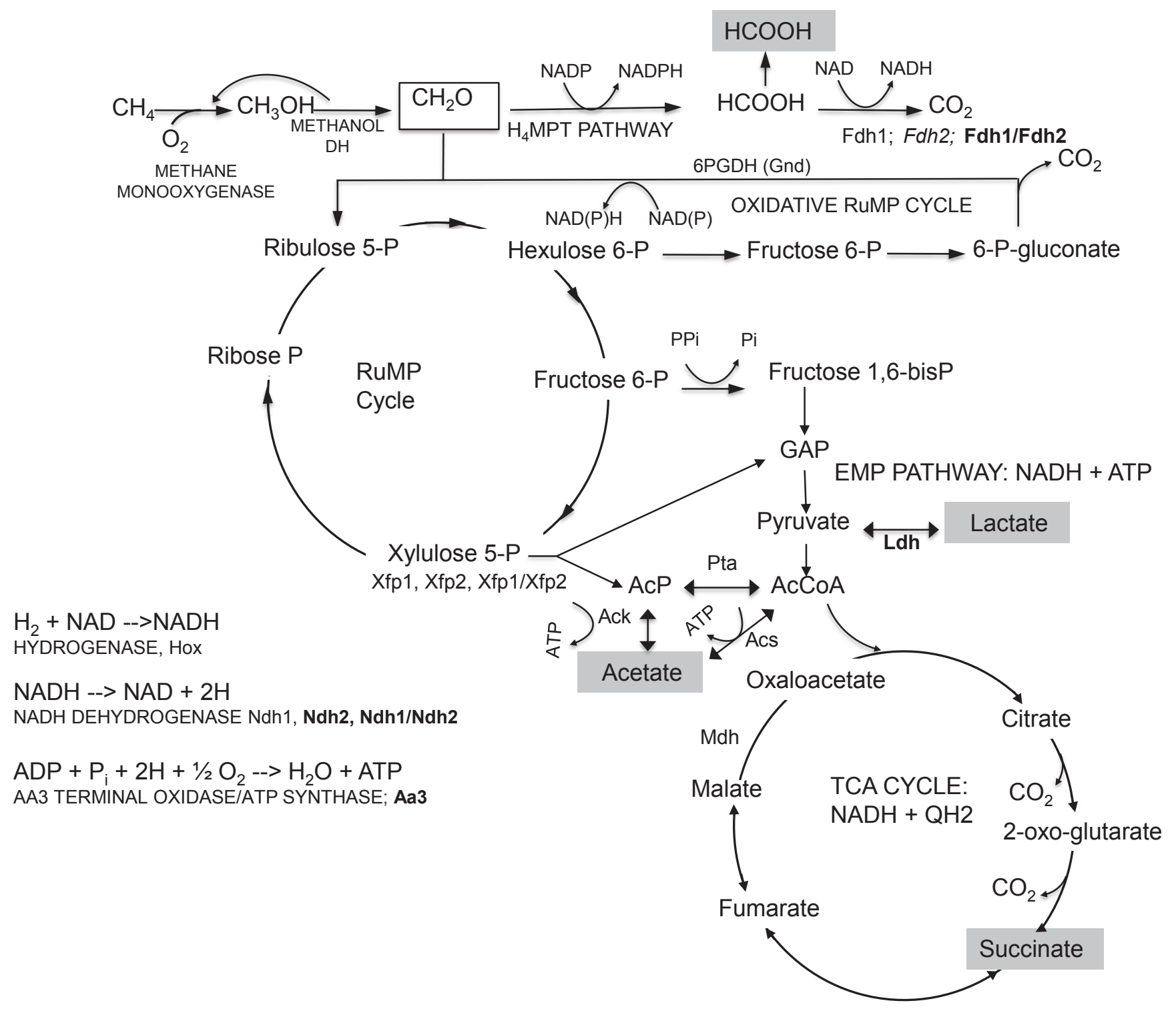

